\title{
A new species of Incestophantes Tanasevitch, 1992 from the high mountains of the Caucasus Major (Arachnida: Aranei: Linyphiidae)
}

\author{
Новый вид Incestophantes Tanasevitch, 1992 из высокогорий \\ Большого Кавказа (Arachnida: Aranei: Linyphiidae)
}

\author{
Stefan Otto*, Andrei V. Tanasevitch** \\ С. Отто, А.В. Танасевич
}

\footnotetext{
* GutsMuthsstrasse, 42, Leipzig 04177, Germany. E-mail: s.otto_bio@gmx.net (Corresponding author)

** Institute of Ecology and Evolution, Russian Academy of Sciences, Leninsky Prospect, 33, Moscow 119071, Russia.

** Институт проблем экологии и эволюции РАН, Ленинский проспект, 33, Москва, 119071 Россия.
}

KEY WORDS: spiders, new species, Micronetinae, Caucasus, Georgia, alpine belt.

КЛЮЧЕВЫЕ СЛОВА: пауки, новый вид, Micronetinae, Кавказ, Грузия, альпийский пояс.

ABSTRACT. The new species, Incestophantes shetekaurii sp.n., is described from the high mountains of the Caucasus Major (Georgia, $2500 \mathrm{~m}$ a.s.1.). This new species is similar to the European-West Siberian $I$. crucifer (Menge, 1866) and to the Crimean I. australis Gnelitsa, 2009, but differs noticeably in the details of the genitalia in both sexes. The generic position of Bolyphantes lagodekhensis (Tanasevitch, 1990), and its differences to I. shetekaurii sp.n., is briefly discussed and illustrated.

РЕЗЮМЕ. Из высокогорий Большого Кавказа (Грузия, 2500 м н.у.м.) описан Incestophantes shetekaurii sp.n. Новый вид близок к европейскозападносибирскому I. crucifer (Menge, 1866) и к крымскому I. australis Gnelitsa, 2009, но отличается деталями строения гениталий обоих полов. Кратко обсуждено систематическое положение Bolyphantes lagodekhensis (Tanasevitch, 1990), его отличия от I. shetekaurii sp.n. проиллюстрированы.

\section{Introduction}

The family Linyphiidae Blackwall, 1859 is a species-rich taxon with a worldwide distribution. Currently 4,497 valid species in 590 genera are known worldwide and more than half of these species $(2,428)$ are distributed in the Palearctic [Tanasevitch, 2014; World Spider Catalog, 2014] — making this the most important zoogeographic region for linyphiid diversity [van Helsdingen, 1984; Marusik \& Koponen 2002]. In the Caucasus Ecoregion the Linyphiidae are represented by 186 species, ranking first in species number above Gnaphosidae (127 species) and Lycosidae (111 species) [Otto, 2014]. Within the genus Incestophantes Tanasevitch, 1992, only I. amotus (Tanasevitch, 1990) has been recorded in the Caucasus Ecoregion so far [Otto, 2014].

\section{Material and methods}

The paper is based on spider material collected by Stefan Otto during a field trip to Khevsureti region in Georgia in July 2013. The type specimens are deposited in the arachnological collection of the Berlin Museum of Natural History (ZMB).

Measurements and drawings were made using a Zeiss SZ 6 stereomicroscope at 50x magnification (all figures except Fig. 2b) and a Carl Zeiss Jena LgOG1 at 200x magnification prepared on slide with cover slip (Fig. 2b).

In Tabs. 1-2 chaetotaxy is given by formulae such as, e.g., 2-1-0-2(3), meaning that the leg segment has two dorsal spines, one pro-, no retrolateral spine, and two or three ventral spines (the apical spines are disregarded). All measurements are given in $\mathrm{mm}$.

The following abbreviations were used in the text and figures: Dp — distal process of distal part of paracymbium; DS - distal part of scapus; E - embolus; EP embolus proper; LC — lamella characteristica; LL lateral lobe; $\mathrm{Mp}$ - median process of distal part of paracymbium; Pc — paracymbium; PMP — posterior median plate; PS - proximal part of scapus (= proscape); PsS pseudoscape; S - stretcher; Sh - shoulder of embolus; TA - terminal apophysis; Th — thumb; TmI - relative position of trichobothrium on the metatarsus of leg I; ZMB - Berlin Museum of Natural History.

\section{Taxonomy}

Family Linyphiidae Blackwall, 1859

Subfamily Micronetinae Hull, 1920

Genus Incestophantes Tanasevitch, 1992

Incestophantes shetekaurii sp.n. Figs 1-11.

HOLOTYPE. O' (ZMB 48660), GEORGIA, Caucasus Major, upper drainage basin of the river Assa, SW of Chimgha near 


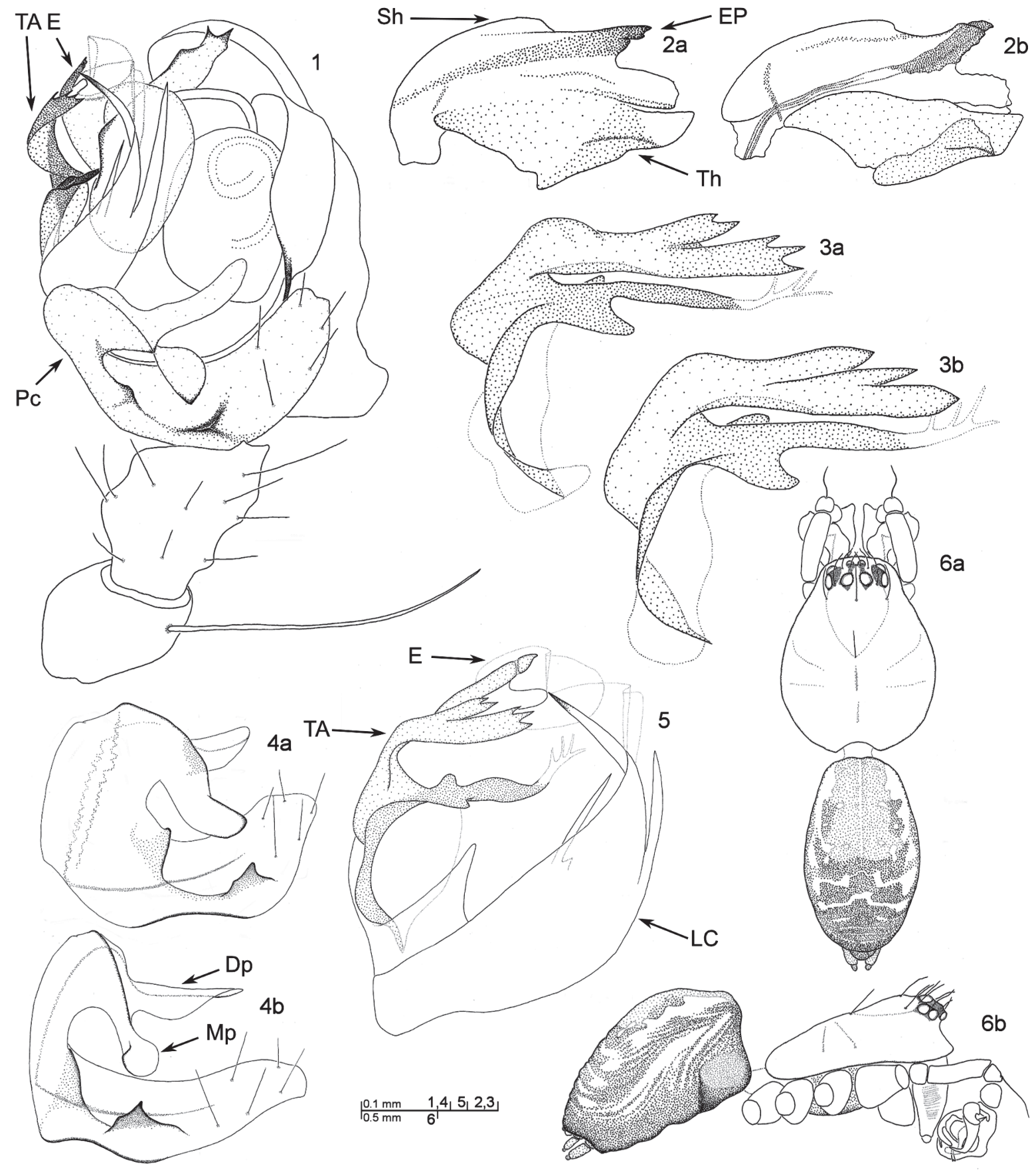

Figs 1-6. Incestophantes shetekaurii sp.n., $O^{7}$ copulatory organs and habitus (paratype: 1-2, 3a, 4-5; holotype: $3 b, 6$ ): 1 - left palp; 2a - embolus at 50x (stereomicroscope); $2 \mathrm{~b}$ - embolus at 200x (transmitted light); $3 \mathrm{a}, \mathrm{b}$ - terminal apophysis; 4 - paracymbium; 5 embolic division; 6a, $6 \mathrm{~b}$ - habitus, dorsal and lateral view, respectively.

Pис. 1-6. Incestophantes shetekaurii sp.n., внешний вид и копулятивные органы о (паратип: 1-2, 3a, 4-5; голотип: 3b, 6): 1 левая пальпа; $2 \mathrm{a}$ - эмболюс, 50-кратное увеличение (стереомикроскоп); $2 \mathrm{~b}$ - эмболюс, 200-кратное увеличение (в проходящем свете); 3a,b - терминальная апофиза; 4 - парацимбиум; 5 - эмболюсный отдел; $6 \mathrm{a}, 6 \mathrm{~b}$ - внешний вид, вид сверху и сбоку, соответственно. 


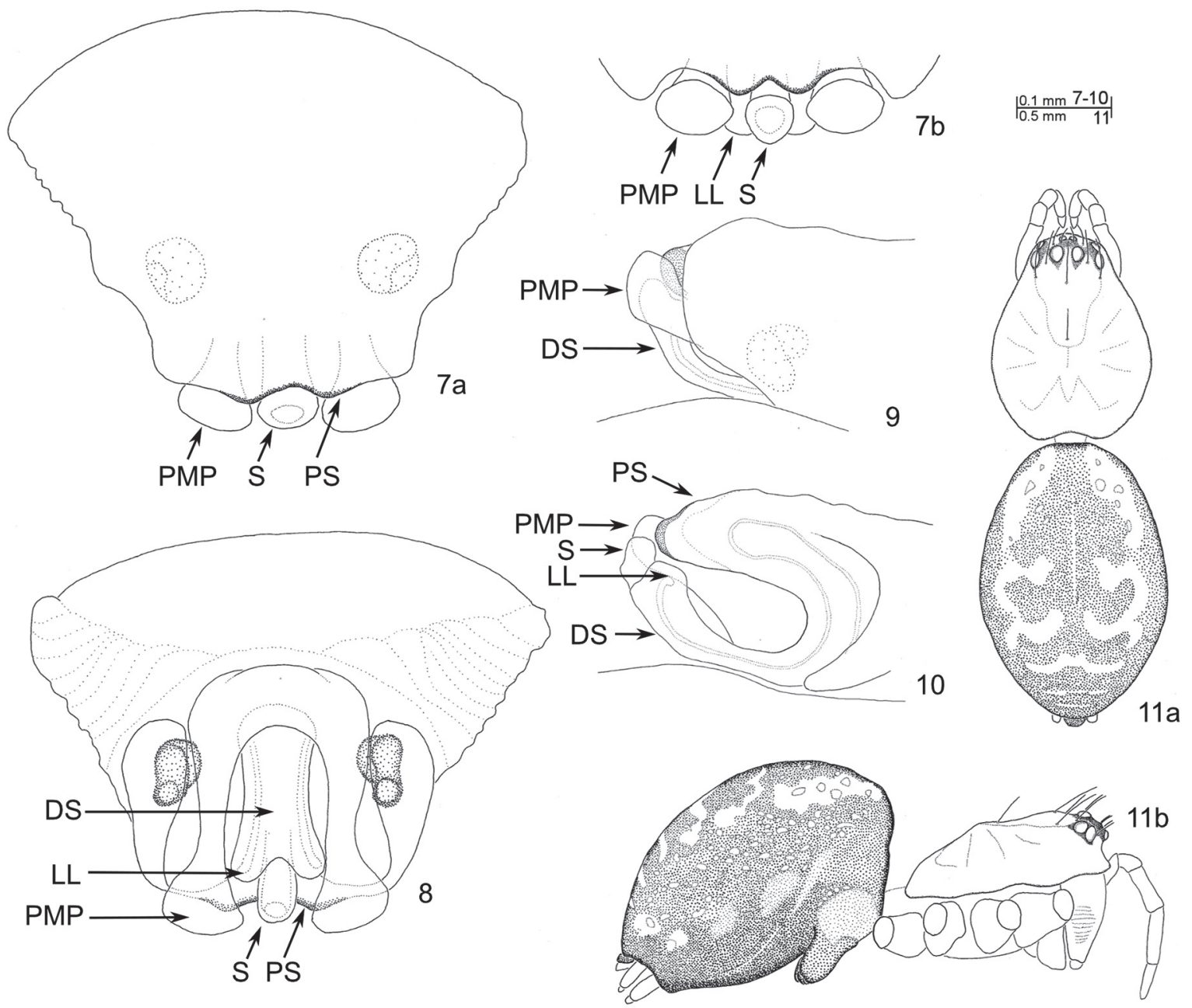

Figs 7-11. Incestophantes shetekaurii sp.n., + copulatory organs and habitus (paratype): 7a — epigyne, ventral view; 7b - distal margin of epigyne, ventro-caudal view; 8,9-epigyne, dorsal and lateral view, respectively; 10 - epigyne, lateral view (left wall and left part of PMP removed); 11a, 11b — habitus, dorsal and lateral view, respectively.

Рис. 7-11. Incestophantes shetekaurii sp.n., внешний вид и копулятивные органы 9 (раratype): 7a - эпигина, вид снизу; 7b дистальный отдел эпигины, вид снизу и сзади; 8,9 - эпигина, вид сверху и сбоку, соответственно; $10-$ эпигина, вид сбоку (левая стенка эпигины и левая доля РМР удалены); 11а - внешний вид, вид сверху и сбоку, соответственно.

Akhieli, on the northern foot of Chimghisklde Ridge (= Kideganis Ridge), $42.62173^{\circ} \mathrm{N} 44.87330^{\circ} \mathrm{E}, 2500 \mathrm{~m}$ a.s.l., alpine zone, rock slide, under slate rock near snow patches, 22.VII.2013, leg. S. Otto.

PARATYPES. $10^{7}, 14$ OP (ZMB 48661), collected together with holotype.

COMPARATIVE MATERIAL. Bolyphantes lagodekhensis (Tanasevitch, 1990): 5 + , GEORGIA, Caucasus Major, upper drainage of the river Arghun, W of Giorgitsminda, eastern slope of Mt. Kamgismagali, $42.62564^{\circ} \mathrm{N} 45.08236^{\circ} \mathrm{E}$, alpine mats, $2600 \mathrm{~m}$ a.s.l., under slate rocks, 2.VIII.2007, leg. S. Otto.

ETYMOLOGY. The specific name is given in honor of the Georgian botanist Prof. Dr. Shamil Shetekauri and his family, who during the last decade have generously supported the first pioneering arachnological research in the mountainous regions of Khevsureti; noun.

DESCRIPTION. Male (measurements of paratype in brackets). Habitus like Fig. 6. Total length 2.61 (2.29), carapace length 1.20 (1.09), carapace width 0.93 (0.81). Carapace color dark yellow; eyes with a black fringe. Chelicerae length $0.56(0.46)$, same color as carapace, unmodified, its basal part with fine stridulation file. Anterior cheliceral margin with two larger teeth in proximal position near the tip of the fangs and one denticle near the fang; posterior cheliceral margin with two denticles near the fang. Legs same color as carapace, distant segments lighter, TmI range 0.18 (0.18). Length of leg segments and chaetotaxy shown in Table 1. Abdomen light gray with dark gray pattern, heart region somewhat brighter. Abdomen length 1.39 (1.26). Venter dark gray. Spinnerets yellow and tinged with black. Palp (Figs 1-5): Patella with a long pointed spine without denticles, cymbium with a posterodorsal outgrowth (Fig. 1). Distal part of paracymbium with a club-shaped median process and a thin sclerotized distal process with a U-shaped profile (Figs 1, 4). Paracymbium with one well-developed proximate tooth and 


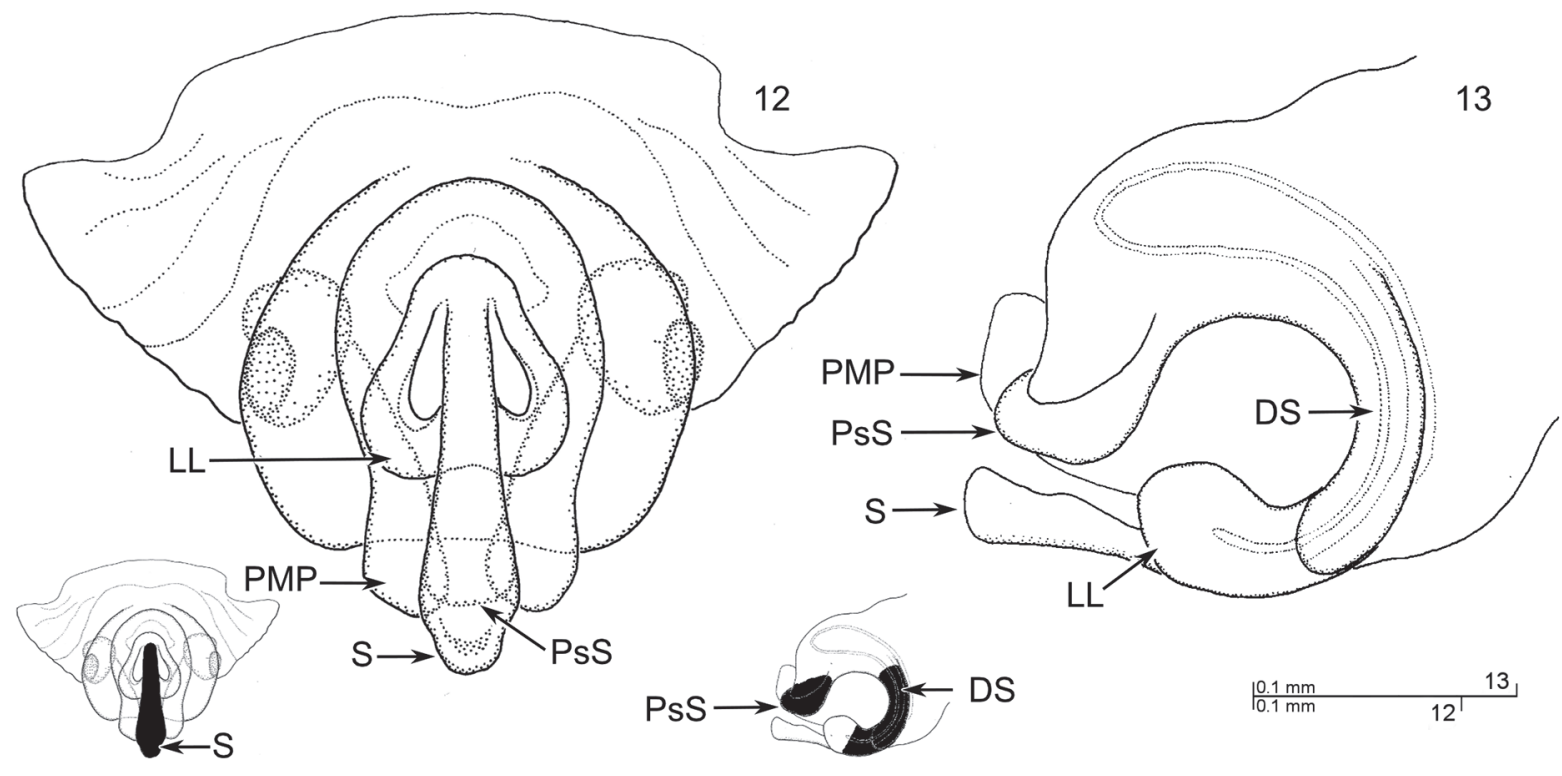

Figs 12, 13. Bolyphantes lagodekhensis (Tanasevitch, 1990), 9 copulatory organs: 12 — epigyne (dorsal view); 13 — epigyne, lateral view (left wall and left part of PMP removed), after Otto, Tanasevitch [2010]. In detail drawings, stretcher, pseudoscape and distal part of scapus are filled with black.

Рис. 12, 13. Bolyphantes lagodekhensis (Tanasevitch, 1990), копулятивные органы $9: 12$ - эпигина, вид сверху; 13 - эпигина, вид сбоку (левая стенка эпигины и левая доля PMP удалены), по Otto, Tanasevitch [2010]. Стретчер, псевдоскапус и дистальная часть скапуса залиты черным.

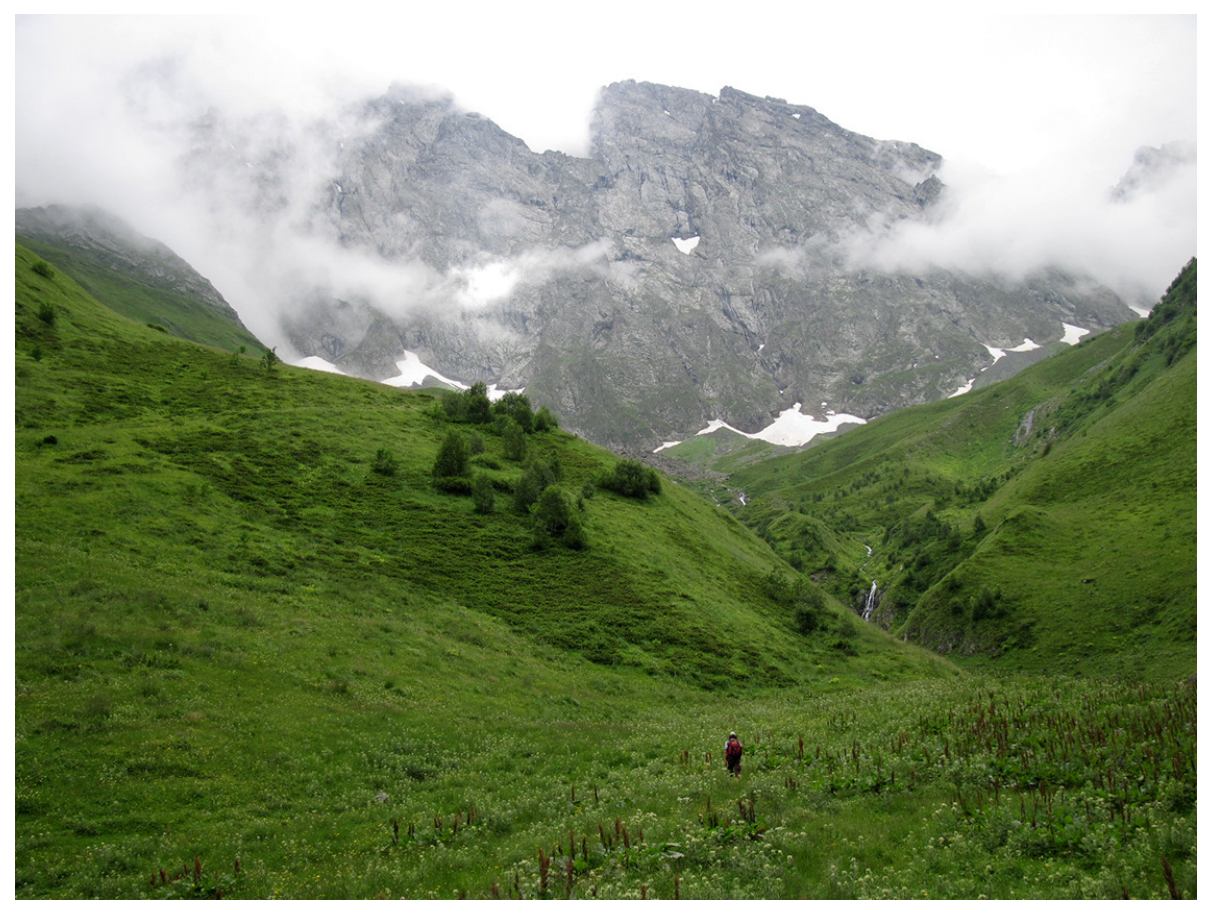

Fig. 14. Habitat of Incestophantes shetekaurii sp.n., Chimghisklde Ridge in Assa Valley, 22th July 2013, photo S. Otto. Specimens were found in rockslides next to the snow patches directly below the rock face.

Рис. 14. Местообитание Incestophantes shetekaurii sp.n. Ущелье Асса, хр. Чимгисклде (июль, 2013, фото С. Отто). 
Table 1. Length of leg segments and chaetotaxy in males of Incestophantes shetekaurii sp.n.: holotype, paratype in brack-

Таблица 1. Длина сегментов ног и хетотаксия самцов Incestophantes shetekaurii sp.n.: голотип, значения для паратипа - в скобках.

\begin{tabular}{|c|c|c|c|c|c|}
\hline Legs & Femur & Patella & Tibia & Metatarsus & Tarsus \\
\hline \multirow{2}{*}{ I: $6.33(5.46)$} & $1.54(1.39)$ & $0.37(0.30)$ & $\begin{array}{c}1.74(1.44) \\
2-1-1-2\end{array}$ & $\begin{array}{c}1.74(1.48) \\
2-0-0-0\end{array}$ & $0.94(0.85)$ \\
& $0-1-0-0$ & - & - & $0.85(0.76)$ \\
\hline \multirow{2}{*}{ II: $5.79(4.92)$} & $1.55(1.30)$ & $0.33(0.31)$ & $1.52(1.26)$ & $1.54(1.30)$ & $2-0-0-0$ \\
& - & - & $2-1-1-1(2)$ & - \\
\hline \multirow{2}{*}{ III: 4,50 (3.81) } & $1.26(1.05)$ & $0.30(0.26)$ & $1.13(0.93)$ & $1.18(1.00)$ & $0.63(0.57)$ \\
& - & - & $2-1-1-0(1)$ & $1(2)-0-0-0$ & - \\
\hline \multirow{2}{*}{ IV: $5.98(4.92)$} & $1.57(1.30)$ & $0.30(0.26)$ & $1.57(1.28)$ & $1.67(1.35)$ & $0.87(0.74)$ \\
& - & - & $2-1-1-0(1)$ & $1-0-0-0$ & - \\
\hline
\end{tabular}

a tooth-like hump in more distal position closer to the distal part of the paracymbium (Figs 1,4). Terminal apophysis consisting of a lower branch with two basal wing-like structures and a thin, white and terminally fanned-out part as well as an elongated upper branch roughly consisting of two parallel blade-like structures with one to three points (Figs 1,3,5). Lamella characteristica wide and with a large laminar part bearing a transparent basal tooth-like lamella and three distal pointed projections, of which the largest median projection is oriented rectangularly compared to the main orientation of the lamella characteristica and bears a thin transparent sail-like lamella in its terminal part (Fig. 5). Serrate part of embolus with a conspicuous shoulder (Fig. 2); thumb large, bipartite, one part rounded and one part bow-like. Embolic division like in Fig. 5.

Female. Habitus like Fig. 11. Total length $2.55 \pm 0.27$, carapace length $1.06 \pm 0.07$, carapace width $0.81 \pm 0.05$. Carapace color and eyes as in the male. Chelicerae length $0.46(n=2)$, color, appearance and stridulation file as in the male. Anterior cheliceral margin with three large teeth; posterior cheliceral margin with four very small teeth near the fang. Leg color as in the male. TmI range $0.19 \pm 0.01$. Length of leg segments and chaetotaxy as in Table 2. Abdomen coloration and spinnerets comparable to the male. Abdomen length $1.63 \pm 0.23$. Epigyne (Figs 7-10). Proscape very short, distal part of scape well developed. Lateral lobes very small. Stretcher short, pit distinct. Posterior median plate hypertrophied, its lateral extension/branches well protruded.

VARIATION. The second (paratype) male specimen differs from the holotype in size as well as in the shape (number of points) of the upper branch of the terminal apophysis (Figs 3a, 3b).

TAXONOMIC REMARKS. Referral of the new species to the genus Incestophantes Tanasevitch, 1992, is supported by the genital structure of both sexes. Female specimens show some affinities to the related genus Bolyphantes C.L. Koch, 1837 but can be easily distinguished from it by lacking a pseudoscape (see below).

The new species is very similar to I. crucifer (Menge, 1866) but males of $I$. shetekaurii sp.n. differ from it by having non-serrate patellar setae; the shape of the distal part of the paracymbium; the shape of the lamella characteristica as well as the shape of the terminal apophysis. Females differ from I. crucifer by a wider and longer proscape, a more narrow distal part of the scape as well as more narrow branches of the posterior median plate (Figs 7, 8).

The new species also shows some affiliation to the recently described Incestophantes australis Gnelitsa, 2009 from the Crimea, but differs from it in the shape of lamella characteristica, the terminal apophysis in the male, the posterior median plate and the wider proscape in the female. Perhaps both species - as well as the only conspecific species in the Caucasus Ecoregion, I. amotus (Tanasevitch, 1990) — are the result of recent divergent evolutionary processes in the Crimea and Caucasus Major, which contributed greatly to the high proportion of endemic spider species in the high mountain ecosystems of the Caucasus [Chaladze et al., 2014]. only.

DISTRIBUTION. Known from the type locality

ADDITIONAL REMARKS. Comparison of the type material of I. shetekaurii sp.n. to Bolyphantes lagodekhensis showed some similarities in the genital structures of both males and females [Tanasevitch, 1990; Otto, Tanasevitch, 2010]. However, a thorough examination of the epigyne of the latter species, including new information on the structure of the epigyne in dorsal view (Figs 12, 13) affirms this species' position in the genus Bolyphantes C.L. Koch, 1837, mainly because of the existence of a pseudoscape, which is lacking in the genus Incestophantes.

ACKNOWLEDGEMENTS. Authors thank Shamil Shetekauri and Tolkha Shetekauri (pictured in Fig. 14) for their support during the field trip. Hans-Joachim Zündorf and Jörn 
Table 2. Length of leg segments and chaetotaxy in females of Incestophantes shetekaurii sp.n. ( $\mathrm{n}=14$, mean \pm standard deviation).

Таблица 2. Длина сегментов ног и хетотаксия самок Incestophantes shetekaurii sp.n. (n=14, среднее \pm стандартное отклонение).

\begin{tabular}{|c|c|c|c|c|c|}
\hline Legs & Femur & Patella & Tibia & Metatarsus & Tarsus \\
\hline I: $5.27 \pm 0.27$ & $\begin{array}{c}1.39 \pm 0.09 \\
0-1-0-0\end{array}$ & $\begin{array}{c}0.33 \pm 0.02 \\
-\end{array}$ & $\begin{array}{c}1.39 \pm 0.08 \\
2-1-1(2)-3(4)\end{array}$ & $\begin{array}{c}1.35 \pm 0.07 \\
2-0-0-0\end{array}$ & $\begin{array}{c}0.82 \pm 0.03 \\
-\end{array}$ \\
\hline II: $4.81 \pm 0.35$ & $\begin{array}{c}1.29 \pm 0.08 \\
-\end{array}$ & $\begin{array}{c}0.31 \pm 0.04 \\
-\end{array}$ & $\begin{array}{l}1.23 \pm 0.15 \\
2-1-1-2(3)\end{array}$ & $\begin{array}{c}1.24 \pm 0.09 \\
2-0-0-0\end{array}$ & $\begin{array}{c}0.74 \pm 0.04 \\
-\end{array}$ \\
\hline III: $3.89 \pm 0.25$ & $\begin{array}{c}1.11 \pm 0.07 \\
-\end{array}$ & $\begin{array}{c}0.27 \pm 0.02 \\
-\end{array}$ & $\begin{array}{c}0.95 \pm 0.07 \\
2-1-1-(0-2)\end{array}$ & $\begin{array}{c}0.98 \pm 0.08 \\
1-0-0-0\end{array}$ & $\begin{array}{c}0.58 \pm 0.06 \\
-\end{array}$ \\
\hline IV: $5.04 \pm 0.28$ & $\begin{array}{c}1.40 \pm 0.09 \\
-\end{array}$ & $\begin{array}{c}0.30 \pm 0.02 \\
-\end{array}$ & $\begin{array}{c}1.30 \pm 0.08 \\
2-1-1-(0-2)\end{array}$ & $\begin{array}{c}1.30 \pm 0.09 \\
1-0-0-0\end{array}$ & $\begin{array}{c}0.75 \pm 0.02 \\
-\end{array}$ \\
\hline
\end{tabular}

Hentschel of the Friedrich Schiller University Jena (Germany) were so kind to tolerate arachnological research during their botanical field trip to Assa Valley. We are grateful to Christo Deltshev who kindly provided some of the literature. Jason Dunlop helped by commenting on the English.

\section{References}

Chaladze G., Otto S., Tramp S. 2014. A spider diversity model for the Caucasus Ecoregion // Journal of Insect Conservation. Vol.18. No.3. P.407-416. DOI 10.1007/s10841-014-9649-1.

Gnelitsa V. 2009. A new species of Incestophantes Tanasevitch, 1992 (Araneae, Linyphiidae) from Ukraine // Stoev P., Dunlop J., Lazarov S. (eds.). A life caught in a spider's web. Papers in arachnology in honour of Christo Deltshev. ZooKeys. Vol.16. P.309-317. DOI: 10.3897/zookeys.16.225.

Helsdingen P., van. 1984. World distribution of Linyphiidae // Pro. $9^{\text {th }}$ Int. Congr. Arachnol. Panama. P.121-126.
Marusik Y.M., Koponen S. 2002. Diversity of spiders in Boreal and Arctic Zones // J. Arachnol. Vol.30. P.205-210.

Otto S. 2014. Caucasian Spiders. A faunistic database on the spiders of the Caucasus. Version 1.4. Internet: http://caucasusspiders.info/ [accessed Aug. 2014].

Otto S., Tanasevitch A.V. 2010. First description of the male of Lepthyphantes lagodekhensis Tanasevitch, 1990 (Arachnida: Aranei: Micronetinae) // Arthropoda Selecta. Vol.19. No.3. P.203-206.

Tanasevitch A.V. 1990. [The spider family Linyphiidae in the fauna of the Caucasus (Arachnida, Aranei)] // Striganova B.R. (ed.). Fauna nazemnykh bespozvonochnykh Kavkaza. Moscow: Nauka Publ. P. 5-114 [in Russian], 235 [English summary].

Tanasevitch A.V. 2014. Linyphiid spiders of the world. Online at http://www.andtan.newmail.ru/list/ [accessed Aug. 2014].

World Spider Catalog. 2014. World Spider Catalog. Natural History Museum Bern. Online at http://wsc.nmbe.ch, version 15.5 [accessed Oct. 2014].

Responsible editor K.G. Mikhailov 